\title{
Intergenerational Functional Solidarity in the Family: The Case of Latvia
}

\author{
SIGNE DOBELNIECE \\ Latvia University of Life Sciences and Technologies, Lielā iela 2, 3001 Jelgava, Latvia \\ Email: signe.dobelniece@llu.lv
}

NADEŽDA KUL̦IGINA

Riga Stradiņš University, Dzirciema iela 16, Kurzemes rajons, 1007 Riga, Latvia

Email: nadezda.kuligina@rsu.edu.Iv

\section{INTRODUCTION}

Relationship among family members belonging to different generations has always been the subject of much discussion both in the classical literature and in the scientific world. Economic, demographic and social processes, along with the trends of globalisation, migration, emancipation, longer life expectancy and population aging, as well as individualism and physical distancing, weakening emotional and social ties, are changing not only the family structure itself (Progress of the World's... 2019; Dzenovska 2006) and family functional possibilities, but also create new conditions for family interaction. Traditional family expectations in Latvia have been associated with the help and support among family members, especially of adult children to parents in their old age. Support from older parents in the care of the younger generation is also expected. Changes in the family structure and the delegation of family functions to institutions raise the question of whether the family continues to provide help and support to its members and whether parents can rely on the support by their children.

Despite the importance of the problem, there is a lack of studies that focus on intergenerational relationships in the family; this topic has not been widely studied in Latvia. A couple of research can be mentioned: Banceviča (2012) has focused on the study of intergenerational solidarity with the emphasis on the macro level; and some aspects - such as views on support, care for grandchildren and mutual support network - are covered by the study of the University of Latvia and the Cross-Sectoral Coordination Centre within the framework of the Generation and Gender Programme (Latvijas gimenes paaudzēs 2019). Our study focuses on some aspects related to the exchange of help between adult children and their parents. The theoretical framework consists of Bengtson's and Roberts' theory of intergenerational solidarity in the family. The aim of the paper is to discuss the manifestations of the functional dimension of intergenerational solidarity in the family and its influencing factors.

Empirical data were collected by the method of web-survey, which took place between June 2019 and January 2020. The sample $(n=410)$ consists of adult children with at least one parent alive. Data were collected from population of Latvia on different aspects of intergenerational solidarity, particularly about its functional dimension, and socio-economic and socio-demographic factors that promote or reduce the mutual exchange of help and support among adult children and parents. 


\section{THEORETICAL FRAMEWORK OF INTERGENERATIONAL SOLIDARITY IN THE FAMILY AND ITS FUNCTIONAL DIMENSION}

The phenomenon of intergenerational solidarity was introduced and its research was initiated in North America. Combining findings of sociological and social psychological studies and theories about the family and its development trends, Bengtson and Roberts (1991) developed their own theory of intergenerational solidarity in the family and elaborated a model for its measurement.

Intergenerational solidarity in the family is defined as a social cohesion between generations or an intergenerational link between parents and children when children have grown up and form their own families; it is a multifaceted, multidimensional construct reflected in six distinct elements of parent-child interaction: affection, association, consensus, resource sharing, the strength of family norms, and the opportunity structure for parent-child interaction (Bengtson, Roberts 1991; Bengtson, Oyama 2007; Yilmaz et al. 2018).

When studying intergenerational solidarity in the family, Bengtson and Roberts (1991) do not consider the family in its traditional sense and do not separate the family by type and composition, rather attention is paid to the basis of the intergenerational solidarity - the relationship between the adult child and the parent, and vice versa, and its different manifestations within six dimensions: associational, affectual, consensual, functional, normative and structural solidarity. Although not all researchers fully agree with Bengtson's model, criticising it for focusing too much on solidarity and harmony, ignoring conflict and nonconsensual aspects of family relationships, this, as Lowenstein (2007) points out, has been a dominant paradigm during last decades.

Researchers have not always studied all six dimensions; most of the research has focused on only one dimension - functional solidarity, which is understood as mutual support, helping and exchange of resources between generations (Bengtson, Settersten 2016; Bengtson, Roberts 1991), containing three main types of support (Kalmijn 2005):

a) practical - helping parents with household chores, caring for parents if they are sick or disabled, or helping parents raise children (care for grandchildren);

b) financial - money that parents give to their children or vice versa. Heritage is also included in this category;

c) social - visiting and paying attention to parents. Often this is understood as emotional support.

Functional solidarity can be looked upon through the prism of altruism (Wolff et al. 2005) and exchange theory (Kalmijn 2005; Coimbra, Mendonca 2013). Exchange can take different forms, for example, as children grow up, parents invest in the child's future, but adult children repay the 'debt' to their parents. Another model sees the assistance provided by an adult child to parents in exchange for future benefits. This exchange includes a certain element of altruism, as heritage and other potential benefits in the future are not guaranteed, especially if there are other heirs. The most common is direct exchange where children help their parents inside and outside the household, while parents help to raise their grandchildren.

Analysis of previous studies shows that researchers focus on various factors, that have impact on functional solidarity: the gender of an adult child (Di Nicola, 2015), marital status and family composition (Connidis, 2015), economic situation and available resources (Ribar, Wilhelm, 2006), culture and traditions (Koyano, 2008). The intensity of support, without the above-mentioned, is affected also by the child's occupation, the parent's health condition, as well as the distance between the adult child's and parent's place of residence, and other factors. Several of them are addressed in this study. 


\section{RESEARCH METHOD AND SAMPLE}

To collect empirical data, quantitative methodology - web-survey method was used. The call to participate in the study was placed on social networks. 410 questionnaires were completed by Latvian residents who have at least one parent alive. $71 \%$ of respondents have both parents alive. In that case, one had to be chosen for whom information would be provided. As a result, $87 \%$ of respondents chose the mother and $13 \%$ the father. About $1 / 3$ of the sample has retired parents but the majority - $65 \%$ - provided answers about the parent which had not reached the age of retirement (it was 63 years and 6 months in 2019 and 63 years and 9 months in 2020).

The questionnaire was based on the Bengtson's and Roberts' model of intergenerational solidarity in the family. To measure functional solidarity, a block of questions was included on the provision and receipt of support within the household (house cleaning, laundry, cooking, personal hygiene, etc.) and outside the household (transport assistance, joint shopping, doctor visits, gardening, etc.). Also questions on financial and emotional support were included.

Descriptive statistics and $p$-value (if it is less than 0.05 , the result is considered as statistically significant) are used for data analysis.

The sample $(n=410)$ consists of $81 \%$ women and $19 \%$ men aged 18 to 62 years, median $=31$ years $($ standard deviation $=11.01)$. More than a half are married or living with a partner, however, about one in three is single. This is understandable when looking at the age structure of the respondents where younger individuals (almost 3/4 are up to 39 years old) dominate. The age structure also influences the occupation of the respondents, so in this study, about a third are students (See Figs. 1-3).

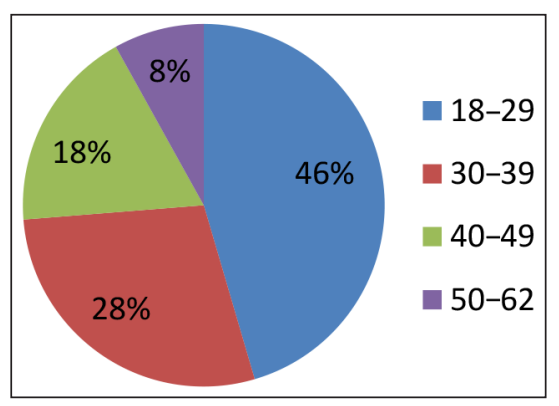

Fig. 1. Sample structure by age (\%)

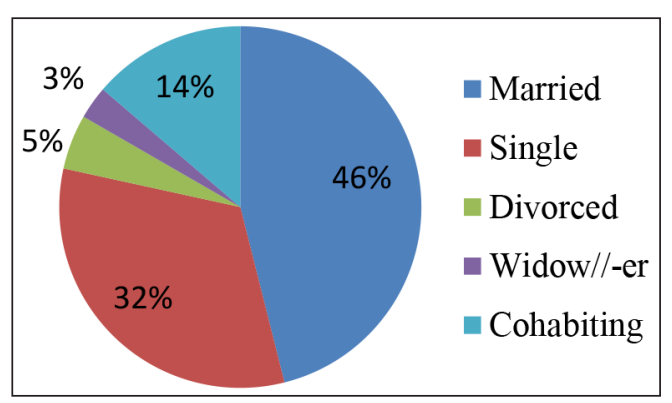

Fig. 2. Sample structure by marital status (\%)

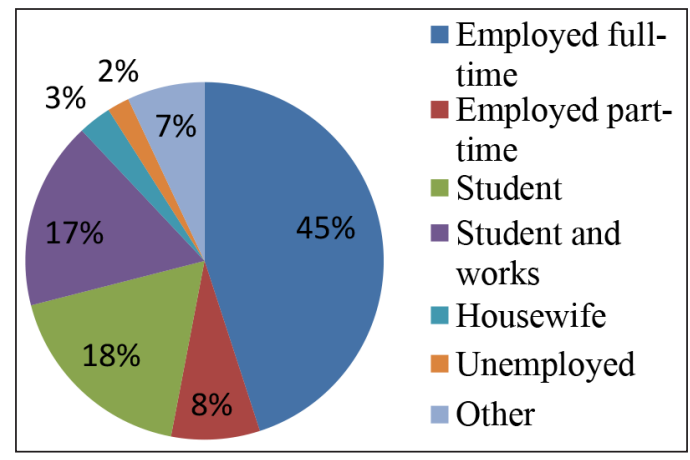

Fig. 3. Sample structure by employment (\%) 
More than a half of the respondents - $60 \%$ - have a child/children; and $88 \%$ have a sister or brother. The respondents are quite well-off by their self-assessment: $12 \%$ rate their current financial situation as very good, $39 \%$ as good, $44 \%$ as average, only $4 \%$ as bad, and $0.5 \%$ as very bad. The fact that every fifth respondent lives with the parent in the same household certainly affects mutual relations and the functional solidarity in the family.

It should be noted that the sample is not representative. The composition of the sample influences the results obtained and limits the degree of generalization, however, it allows identifying the dominant trends in the manifestations of the functional dimension of intergenerational solidarity in the family.

\section{EXCHANGE OF HELP BETWEEN AN ADULT CHILD AND A PARENT}

In the study, the functional solidarity takes the form of mutual assistance within and outside the household, financial support and emotional support provided between the adult child and the parent. The study also includes the help received from parents in caring for grandchildren.

The results obtained on the trends of the provision and receipt of intergenerational support in this study are similar to the trends observed in other countries, for example, Norway, England, Germany, Spain and Israel (Lovenstein, Daatland 2006). More than a half of the respondents (59\%) has helped their parents with household work (household cleaning, laundry, cooking, personal hygiene, etc.) in the last 3 months, much more - three quarters (76\%) have been involved in providing support outside the household (help with transport, general shopping, doctor visits, gardening, etc.). There are more respondents who have provided assistance than those who have received it, with the exception of financial support, where the opposite trend is observed. However, a quite significant difference in respect to financial support can be noted between our results in Latvia and other countries: it is provided by $43 \%$ (in the above-mentioned countries $4-23 \%$ ) and received by $55 \%$ (7-47\%, respectively). There are also some differences in the direction of financial flow. Higher rates of financial support in Latvia may reflect different economic situations of the countries in question, but they can also be caused by cultural-historical factors (Coimbra, Mendonca 2013), as well as family traditions and the financial situation of family members. In general, the data allow concluding that various manifestations of the functional solidarity are found in Latvian families represented in our sample.

\section{SOCIO-DEMOGRAPHIC FACTORS}

Previous studies (Silverstein et al. 1995; Grundy, Henretta 2006; Ribar, Wilhelm 2006) reveal the impact of socio-demographic and socio-economic factors on intergenerational solidarity in the family, including functional solidarity.

\section{GENDER AND AGE}

Analysing the functional assistance by the adult child's gender (son or daughter), data show that both women and men report higher rates of provided than received help. There is no significant gender difference $(p=0.38-0.43(p>0.05))$ in provided help in the household and outside it (Table 1).

The difference appears in receiving help of childcare: adult daughters get it almost twice as more as adult sons ( 45 and $21 \%$, respectively $(p=0.016<0.05)$ ). It can be assumed that this is because the daughters are emotionally closer to their mothers (Dykstra, Fokkema 2011), 
Table 1. Provided and received support by gender and age (\%)

\begin{tabular}{c|c|c|c|c|c|c|c}
\hline \multirow{2}{*}{ Gender } & \multicolumn{2}{|c|}{ Help provided to parents } & \multicolumn{4}{c}{ Help received from parents } \\
\cline { 2 - 9 } & $\begin{array}{c}\text { In the } \\
\text { household }\end{array}$ & $\begin{array}{c}\text { Outside the } \\
\text { household }\end{array}$ & $\begin{array}{c}\text { Financial } \\
\text { support }\end{array}$ & $\begin{array}{c}\text { In the } \\
\text { household }\end{array}$ & $\begin{array}{c}\text { Outside the } \\
\text { household }\end{array}$ & $\begin{array}{c}\text { Financial } \\
\text { support }\end{array}$ & $\begin{array}{c}\text { Child } \\
\text { care }\end{array}$ \\
\hline Male & 56 & 77 & 49 & 46 & 49 & 49 & 21 \\
\hline Female & 60 & 76 & 45 & 43 & 56 & 56 & 45 \\
\hline \multicolumn{7}{|c|}{ Age } \\
\hline $18-29$ & 76 & 76 & 34 & 54 & 74 & 72 & 29 \\
\hline $30-39$ & 47 & 76 & 43 & 44 & 45 & 44 & 62 \\
\hline $40-49$ & 35 & 78 & 49 & 24 & 30 & 41 & 38 \\
\hline $50-62$ & 59 & 71 & 82 & 29 & 35 & 29 & 35 \\
\hline
\end{tabular}

and the fact that women are still more involved in childcare in many families is also having an impact, so more women than men report received assistance from their parents in this area. The results of the study also show some gender differences in the provision and receipt of financial support between a child-son and a child-daughter: more daughters receive than the sons, and fewer daughters provide. Thus, it can be pointed out that the gender of an adult child has some effect on intergenerational functional solidarity. However, our results differ from those obtained in the studies in other countries, for example, The Netherlands (Dykstra, Fokkema 2011) and Germany (Nauck, Steinbach 2009), where daughters more often provide domestic help to parents than sons.

The results obtained in relation to the age at first seem surprising and contradict the expected - the greatest exchange of help in the household and also outside it takes place in the youngest respondents (18-29 years) and their parents. This may be explained by the fact that young, financially dependent adult children live with their parents and share a common household. However, other age groups are also involved in supporting their parents, especially outside the household. The financial support provided to parents increases with the age of the respondents; up to $82 \%$ of those aged 50-62 have provided it. The opposite trend is observed in receiving financial support from parents, which decreases from $72 \%$ in the youngest age group to $29 \%$ in the oldest. A similar trend in relation to help received from parents both at home and outside the household is observed.

Analysis of the data shows that the age of the adult child affects the intensity and direction of the flow of assistance, but this should not be seen in isolation from other factors that may be related to the respondent's age, such as occupation, financial situation, having children, etc., and their impact on intergenerational functional solidarity should not be neglected.

\section{MARITAL STATUS}

The marital status of the adult child, as well as having own children in the family, are factors that have a significant impact on functional solidarity. As the data show, there are significant differences between married and unmarried children in different forms of support (Table 2).

The results show that single adult children are more likely to provide functional assistance to their parents than married children, at the same time they receive more financial support from their parents. This is contrary to what Dykstra (1998) has found, but to some extent 
Table 2. Provided and received support by marital status (\%)

\begin{tabular}{c|ccc|c|c|c|c}
\hline \multirow{2}{*}{$\begin{array}{c}\text { Marital } \\
\text { status }\end{array}$} & \multicolumn{2}{|c|}{ Help provided to parents } & \multicolumn{4}{c}{ Help received from parents } \\
\cline { 2 - 9 } & $\begin{array}{c}\text { In the } \\
\text { household }\end{array}$ & $\begin{array}{c}\text { Outside the } \\
\text { household }\end{array}$ & $\begin{array}{c}\text { Financial } \\
\text { support }\end{array}$ & $\begin{array}{c}\text { In the } \\
\text { household }\end{array}$ & $\begin{array}{c}\text { Outside the } \\
\text { household }\end{array}$ & $\begin{array}{c}\text { Financial } \\
\text { support }\end{array}$ & $\begin{array}{c}\text { Child } \\
\text { care }\end{array}$ \\
\hline Married & 46 & 74 & 41 & 33 & 47 & 48 & 54 \\
\hline Single & 73 & 77 & 32 & 58 & 67 & 73 & 20 \\
\hline Divorced & 60 & 80 & 80 & 50 & 20 & 40 & 60 \\
\hline Widow/-er & 67 & 67 & 100 & 0 & 33 & 0 & 33 \\
\hline Cohabiting & 67 & 78 & 56 & 44 & 63 & 41 & 37 \\
\hline With a child & 47 & 75 & 49 & 34 & 43 & 45 & 16 \\
\hline $\begin{array}{l}\text { Without } \\
\text { children }\end{array}$ & 77 & 77 & 34 & 57 & 72 & 69 & 0 \\
\hline
\end{tabular}

is in line with Connidis' (2015) findings on greater support for parents of unmarried daughters without children. Our results with high probability can be explained by the composition of our sample where young individuals prevail. A significant part of single adult children continue living in their parents' homes and are more likely to provide parents with functional assistance in exchange for financial support from them. Another argument that may explain the results obtained is that adult unmarried children are mostly young people who are continuing their education and are not financially stable, so the parents support them.

\section{SOCIO-ECONOMIC FACTORS}

General trend is that those who have more resources - finances and time - available are more likely to support their parents or adult children (Ribar, Wilhelm 2006). Our results are somewhat different in this respect. According to the results of the study, students provide the most help to their parents, not only in the household, but also outside. At the same time, unlike working or non-working adult children, they receive the most financial assistance from a parent. However, adult children who combine studying with work do not have the opportunity to provide regular domestic help to their parents possibly due to lack of time, but they help their parents outside the household and are less dependent on their parents financially (Table 3 ).

The analysis shows that there is a significant impact of the time dimension in the provision of help and possibly also the age of the respondents and whether they share a household with their parents play some role. Additional research is needed to explain why non-working adult children help their parents so little in the household. It is also difficult to explain the fact that about half of non-working adult children provide financial assistance to their parents.

The results of the study show the effect of self-assessment of financial situation on the exchange of help, especially in the household. The general trend is that better financial situation of the adult child reduces the involvement of both children and parents in the exchange of support. The flow of financial assistance is mostly from parents to children with a poor or very poor material condition. Interestingly, wealthy children also receive financial support from their parents (21\%). These results allow assumption that financial assistance is affected not only by the availability or lack of resources, but also by other factors. 
Table 3. Provided and received support by occupation and financial situation (\%)

\begin{tabular}{|c|c|c|c|c|c|c|c|}
\hline & \multicolumn{3}{|c|}{ Help provided to parents } & \multicolumn{4}{|c|}{ Help received from parents } \\
\hline & $\begin{array}{c}\text { In the } \\
\text { household }\end{array}$ & $\begin{array}{l}\text { Outside the } \\
\text { household }\end{array}$ & $\begin{array}{l}\text { Financial } \\
\text { support }\end{array}$ & $\begin{array}{c}\text { In the } \\
\text { household }\end{array}$ & $\begin{array}{l}\text { Outside the } \\
\text { household }\end{array}$ & $\begin{array}{c}\text { Financial } \\
\text { support }\end{array}$ & $\begin{array}{l}\text { Child } \\
\text { care }\end{array}$ \\
\hline \multicolumn{8}{|c|}{ Occupation } \\
\hline Full-time & 48 & 72 & 42 & 30 & 40 & 42 & 40 \\
\hline Part-time & 67 & 93 & 47 & 47 & 47 & 40 & 53 \\
\hline Student & 84 & 84 & 30 & 65 & 81 & 78 & 32 \\
\hline $\begin{array}{l}\text { Student and } \\
\text { works }\end{array}$ & 66 & 74 & 54 & 49 & 66 & 66 & 43 \\
\hline $\begin{array}{c}\text { Does not } \\
\text { work }\end{array}$ & 36 & 55 & 45 & 55 & 36 & 64 & 45 \\
\hline \multicolumn{8}{|c|}{ Financial situation - self-assessment } \\
\hline Very good & 42 & 71 & 42 & 42 & 42 & 21 & 29 \\
\hline Good & 58 & 76 & 48 & 39 & 53 & 59 & 51 \\
\hline Average & 62 & 77 & 41 & 45 & 57 & 59 & 35 \\
\hline Bad/very bad & 90 & 80 & 30 & 70 & 80 & 60 & 30 \\
\hline
\end{tabular}

\section{STATUS OF PARENTS}

The logical assumption is that as parents get older their health deteriorates, so they need more support. The opposite trend follows from the results of this study, especially with regard to help to parents in the household (Table 4).

In respect to financial support differences between two groups of parents - retired and non-retired - are significant $(p=0.00 ; p<0.05)$ : more children provide it to retired than non-retired parents and fewer receive it from retired parents. The trend is understandable given the low level of pensions in Latvia (CSB 2020), thus the financial opportunities of pensioners are limited.

Table 4. Provided and received support by parent's situation (\%)

\begin{tabular}{|c|c|c|c|c|c|c|c|}
\hline & \multicolumn{3}{|c|}{ Help provided to parents } & \multicolumn{4}{|c|}{ Help received from parents } \\
\hline & $\begin{array}{c}\begin{array}{c}\text { In the } \\
\text { household }\end{array} \\
\end{array}$ & $\begin{array}{l}\text { Outside the } \\
\text { household }\end{array}$ & \begin{tabular}{|c|} 
Financial \\
support
\end{tabular} & $\begin{array}{c}\text { In the } \\
\text { household }\end{array}$ & $\begin{array}{l}\text { Outside the } \\
\text { household }\end{array}$ & \begin{tabular}{|c} 
Financial \\
support
\end{tabular} & $\begin{array}{l}\text { Child } \\
\text { care }\end{array}$ \\
\hline \multicolumn{8}{|c|}{ Status of a parent } \\
\hline Non-retired & 68 & 77 & 35 & 47 & 64 & 64 & 39 \\
\hline Retired & 43 & 75 & 57 & 36 & 38 & 37 & 44 \\
\hline \multicolumn{8}{|c|}{ Health condition of a parent } \\
\hline Very good & 78 & 83 & 22 & 67 & 78 & 67 & 22 \\
\hline Good & 54 & 76 & 35 & 39 & 54 & 57 & 42 \\
\hline Average & 64 & 74 & 55 & 49 & 58 & 53 & 47 \\
\hline $\begin{array}{c}\text { Bad/very } \\
\text { bad }\end{array}$ & 50 & 75 & 50 & 25 & 29 & 42 & 29 \\
\hline
\end{tabular}


Two trends emerge from the analysis of the impact of parent's health condition on the exchange of functional assistance. One that might contradict expectations is that more respondents report helping parents in good health than those in poor health. Here, the explanation may be related to the sample structure. The second trend is that with the deteriorating of health of parents, increases the number of children providing and decreases the number of those receiving financial support.

Regarding mutual emotional support between family members, it can be stated that $86 \%$ of adult children emotionally support their parent and $80 \%$ receive it from their parent. Emotional support is not affected by age, gender or socio-economic factors, and is similar to other research findings.

\section{CONCLUSIONS}

Functional solidarity is one of the six components of intergenerational solidarity in the family. It includes both the provision and receipt of assistance between adult children and parents, as well as mutual financial and emotional support. Parents continue to help their children even after they have grown up and have their own families, and adult children support parents.

The results of the study show that the flow of help between an adult child and a parent is unevenly distributed, the direction and intensity of help are influenced by several factors: adult child's age, marital status and existence of a child, occupation and financial situation. Important for intergenerational functional solidarity are also the status of parents - retired or non-retired, as well as the health condition. Unlike other studies, this does not show a significant effect of the adult child's gender on functional solidarity $(p>0.05)$, which probably is determined by the study sample.

The study revealed the following trends: younger adult children provide more support in the household and receive more financial support than other age groups; respondents having a child receive and provide less assistance than respondents who do not have children; financial assistance from parents is more frequent to women than men, and if the financial situation of an adult child is worse. Depending on the health condition of the parents, there are two trends observed - the exchange of help is more intensive with parents in good health than those who are in poor health, and the worse the health of parents is, the more likely adult children receive less support than they provide.

To allow deeper and more substantiated analysis and explanation of the impact of different factors on intergenerational functional solidarity in Latvia, a more in-depth study with a larger and representative sample would be needed.

Received 12 April 2021

Accepted 23 November 2021

\section{References}

1. Banceviča, M. 2012. Starppaaudžu solidaritāte Latvijā - solidaritāte attiecībā prêt vecākās paaudzes cilvēkiem sabiedrības diskursā, paaudžu kontekstā un tās pamatojums. Maǵistra darbs. LU SZF.

2. Bengtson, V. L.; Oyama, P. S. 2007. Intergenerational Solidarity: Strengthening Economic and Social Ties. United Nations Headquarters, New York. Available at: https://www.un.org/esa/socdev/unyin/documents/egm_unhq_oct07_bengtson.pdf

3. Bengtson, V. L.; Roberts, R. E. L. 1991. 'Intergenerational Solidarity in Aging Families: An Example of Formal Theory Construction', Journal of Marriage and the Family 53(4): 856-870. Available at: http://www. suz.uzh.ch/dam/jcr:ffffffff-df42-7cac-0000-0000125afd0d/Bentson.pdf 
4. Bengtson, V. L.; Settersten, R. A. 2016. Handbook of Theories of Aging. 3rd. edn. Springer Publishing Company. Available at: http://ghttp.48653.nexcesscdn.net/80223CF/springer-static/media/samplechapters/9780826129420/9780826129420_chapter.pdf

5. Coimbra, S.; Mendonca, M. 2013. 'Intergenerational Solidarity and Satisfaction with Life: Mediation Effects with Emerging Adults', Paidera (Ribeirao Preto) 23(55): 161-169. Available at: https://www.researchgate.net/publication/262709315_Intergenerational_Solidarity_and_Satisfaction_With_Life_ Mediation_Effects_With_Emerging_Adults

6. Connidis, I. A. 2015. 'Exploring Ambivalence in Family Ties: Progress and Prospects', Journal of Marriage and Family 77(1): 77-95.

7. CSB. 2020. Pensionāru skaits un vecuma pensijas vidējais apmērs. Available at: https://www.csb. gov.lv/lv/statistika/statistikas-temas/socialie-procesi/sociala-drosiba/tabulas/sd010c/pensionaru-skaits-un-vecuma-pensijas/

8. Di Nicola, P. 2015. 'Care Work between Defamilialization and Commodification', Italian Sociological Review 5(2): 189-205.

9. Dzenovska, I. 2006. Eiropas ğimenesizvēles brīvība. Available at: http://providus.lv/article/eiropas-gimenes-izveles-briviba

10. Dykstra, P. A. 1998. 'The Effects of Divorce on Intergenerational Exchanges in Families', Sociologia Neerlandica 33(2): 77-98. Available at: https://www.researchgate.net/publication/254803830_The_ Effects_of_Divorce_on_Intergenerational_Exchanges_in_Families

11. Dykstra, P. A.; Fokkema, T. 2011. Relationships Between Parents and Their Adult Children: A West European Typology of Late-life Families. Available at: https://www.researchgate.net/publication/228462592_ Relationships_between_parents_and_their_adult_children_A_West_European_typology_of_late-life_ families

12. Grundy, E.; Henretta, J. C. 2006. 'Between Elderly Parents and Adult Children: A New Look at the Intergenerational Care Provided by the "Sandwich Generation", Ageing and Society 26(5): 707-722.

13. Kalmijn, M. 2005. Intergenerational Solidarity: A Review of Three Theories and Their Evidence. Available at: https://pdfs.semanticscholar.org/6353/fdaed66c1f3e7b3f28679803fe4bbe740dc8.pdf

14. Koyano, W. 2008. 'Filial Piety and Intergenerational Solidarity in Japan', Australasian Journal on Ageing 15(2): 51-56.

15. Latvijas gimenes paaudzēs 2018, Analītisks ziṇojums. 2019. Available at: http://petijumi.mk.gov.lv/sites/ default/files/title_file/Latvijas-gimenes-paaudzes-2018.pdf

16. Lowenstein, A. 2007. 'Solidarity-Conflict and Ambivalence: Testing Two Conceptual Frameworks and Their Impact on Quality of Life for Older Family Members', Journal of Gerontology: Social Sciences 62B(2): $100-107$.

17. Lowenstein, A.; Daatland, S. O. 2006. 'Filial Norms and Family Support in a Comparative Crossnational Context: Evidence from the OASIS Study', Ageing \& Society 26: 203-223. Available at: https:// www.uv.es/=atortosa/filialnorms-OASIS.pdf

18. Nauck, B.; Steinbach, A. 2009. Intergenerational Relationships. Available at: https://www.researchgate.net/ publication/46455069_Intergenerational_Relationships

19. Progress of the World's Women 2019-2020. Families in a Changing World. 2019. UN Women. Available at: https:// reliefweb.int/sites/reliefweb.int/files/resources/Progress-of-the-worlds-women-2019-2020-en.pdf

20. Ribar, D. C.; Wilhelm, M. O. 2006. 'Exchange, Role Modeling and the Intergenerational Transmission of Elder Support Attitudes: Evidence from Three Generations of Mexican-Americans', Journal of SocioEconomics 35(3): 514-531.

21. Silverstein, M.; Parrott, T. M.; Bengtson, V. L. 1995. 'Factors That Predispose Middle-Aged Sons and Daughters to Provide Social Support to Older Parents', Journal of Marriage and Family 57(2): 465-475.

22. Wolff, F.; Spilerman, S.; Attias-Donfut, C. 2005. Do Parents Help More Their Less Well-off Children? Evidence From a Sample of Migrants to France. Available at: https://www.researchgate.net/publication/23748585_ Do_Parents_Help_More_their_Less_Well-Off_Children_Evidence_from_a_Sample_of_Migrants_to_ France

23. Yilmaz, N.; Hazer, O.; Öztürk, M. S. 2018. 'Intergenerational Solidarity and Life Satisfaction in Elderly', Turkish Journal of Geriatrics 21(3): 429-437. Available at: http://geriatri.dergisi.org/uploads/pdf/pdf_ TJG_1066.pdf 
SIGNE DOBELNIECE, NADEŽDA KUL̦IGINA

\title{
Kartų funkcinis solidarumas šeimoje: Latvijos atvejis
}

\author{
Santrauka \\ Globalizacija, migracija, visuomenès senejjimas ir kiti socialiniai procesai veikia šeimą ir \\ šeimos narių santykius, ypač skirtingų kartų ryšius šeimose. \\ Straipsnyje demesys skiriamas V. L. Bengtsono ir R. E. L. Robertso pristatytam kartu \\ solidarumui šeimoje, ypač vienai jo dimensiju - funkciniam solidarumui, aiškinamasi, \\ kaip ji veikia socialiniai demografiniai ir socialiniai ekonominiai veiksniai. Empiriniai \\ duomenys buvo gauti atlikus internetinę apklausą $2019 \mathrm{~m}$. birželio - $2020 \mathrm{~m}$. sausio \\ mèn. Latvijoje $(\mathrm{N}=410)$. \\ Gauti rezultatai rodo, kad bendra paramos tarp kartų teikimo ir gavimo tendencija \\ yra panaši ị kitose šalyse pastebètas tendencijas. Funkcinị solidarumą veikia suaugusio \\ vaiko amžius, šeiminè padètis, profesija ir finansinè padètis, taip pat tėvų statusas - ar jie \\ yra senatvès pensininkai, ar ne. Reikšmingą poveikị kartų funkciniam solidarumui atlie- \\ ka tèvų sveikatos būklè. Mažiau svarbi yra vaiko lytis, išskyrus finansinès paramos sritị.
}

Raktažodžiai: kartų solidarumas šeimoje, funkcinis solidarumas, suaugusių vaikų ir tèvų tarpusavio paramos mainai 